\title{
THE ASSOCIATION OF TEACHERS IN TECHNICAL INSTITUTIONS (I904-I4)
}

\section{A CASE-STUDY ON THE ORIGINS, FORMATION AND GROWTH OF A WHITE-COLLAR ORGANIZATION*}

The purpose of this essay is to examine the emergence and development, between 1904 and 1914, of the Association of Teachers in Technical Institutions. A main conclusion is that the ATTI, in being mainly concerned with its members' employment interests, was implicitly a trade union despite continual protestations by both officers and members that the Association was a professional body and would not "degenerate into a mere trades union [...]. For people of education, like teachers, [...] it is wrong to begin at the salary end". ${ }^{1}$ In the first place, therefore, this paper is an investigation into certain aspects of the early history of a white-collar union, in this case the organization whose membership was drawn initially from among a small group of teachers in local authority technical institutes in England at the beginning of this century. ${ }^{2}$ Secondly, however, insofar as the technical

* In preparing this article I have used the Association's archive material at its headquarters in Hamilton House, London. For this I should like to thank the Association and those members of its staff who, by their help, made my task simpler. I also wish to express my thanks to Mr F. Kool and Mrs M. W. H. Schreuder of the Editorial Board for their useful comments on an earlier draft of this paper.

1 Report of the Annual General Meeting, 27 October 1906, ATTI Archives, Vol. II: Miscellaneous correspondence and documents, January 1906 - May 1907, ATTI Library, Hamilton House, London. By early 1907, however, with the Association established on a firm national basis, Council had surveyed all members on their salaries, pension rights, hours worked etc. in order to "draw up a 'Schedule of Salaries' [...] which shall form a standard below which no salary ought to fall" (Salary Survey Form, 15 March 1907, ibid.). Subsequently the Association urged the Board of Education "to make it a condition of the continuation of grants that some such scale be adopted by the Institutions which they inspect" (Executive Committee Minutes, 22 December 1908, ATTI Archives, Vol. XVII: Minutes of General Purposes Committee Meetings, 1904-1907; Minutes of Executive Committee Meetings, 1907-1911).

${ }^{2}$ For membership figures from 1904-1914 infra, Table 1. By 1970 the ATTI (now affiliated to the Trades Union Congress) had a membership of about 30,000 out of a total 46,000 full-time teachers in British further and higher education outside of the universities. The Technical Journal, March 1970, p. 8. 
teachers of this period saw themselves as professional people for whom trade unionism was inappropriate, the case-study also, in passing, illustrates the common conflict over the goals sought by most teachers' organizations at some time during their evolution as to whether they "should be concerned only with professional matters or should also fight for better salaries". ${ }^{1}$

The association of teachers for mutual improvement in their employment is probably as old as the occupation itself. Certainly by the $1830 \mathrm{~s}$, according to one commentator, attempts to form stable local associations of school-teachers were made in parts of England, ${ }^{2}$ although it was not until the 1850 s that any national associations appeared, like the General Associated Body of Church Schoolmasters in England and Wales and the United Association of Schoolmasters. ${ }^{3}$ Yet the first truly national and effective body was the National Union of Elementary Teachers whose initial conference was held on 10 September $1870 .{ }^{4} \mathrm{As}$ its name implied it drew its membership from among teachers in the state "elementary" schools and it was, by 1900, the largest teachers' organization in England with 43,621 members. ${ }^{5}$

By this time other associations of teachers, both in the state elementary sector and the private sector, had been established. ${ }^{6}$ Among the former may be included the National Federation of Class Teachers (founded in 1892), the National Association of Head Teachers (1897) and the National Association of Non-Collegiate Certificated Teachers (1899). In the private schools, organizations of headteachers had preceded those among assistants, where the Incorporated Association of Headmistresses (1874) was followed by the Incorporated Association of Assistant Mistresses (1884), and that of the Incorporated Association of Headmasters (1890) by the Incorporated Association of Assistant

\footnotetext{
${ }^{1}$ A. Blum (ed.), Teacher Unions and Associations (Urbana, 1969), p. viii. In the event, the subsequent history of the ATTI has shown that the realities of salary negotiation for its members have become of greater importance than the falsely perceived sense of occupational status of the Association's founder members and their colleagues.

2 A. Tropp, The School Teachers (London, 1957), p. 44.

3 Ibid., pp. 51 and 54.

"The word "elementary" was dropped in 1889, ibid., p. 109.

5 A. Tropp, "Elementary Schoolteachers as a Professional Group: 1800 to the present day", London Ph.D. thesis 1954, Appendix, p. xxviii.

- There was, of course, a considerable social gulf between the teachers in the state and the private schools and they would be unlikely to form "common" associations.
} 
Masters (1891). ${ }^{1}$ But it was not until 22 October 1904 that the inaugural meeting of the ATTI was held at Birkbeck College, London. ${ }^{2}$

Since other groups of teachers had their own organizations before $1900,{ }^{3}$ what can account for the absence of a body representing the interests of English technical teachers? ${ }^{4}$ One factor was the slow rate of growth of English technical education for most of the nineteenth century, hence compared with other teachers, technical "instructors" were few in number and were dispersed in small institutes throughout the country. The spasmodic growth of "technical instruction", certainly until the 1890 s, derived partly from disinterest and even hostility among employers towards it, and partly from the lack of economic pressure to improve the performance of the industrial labour force until late in the century. Yet, most of all, it was the reluctance of the state to finance education in general and technical education in particular that precluded its expansion until economic and other forces caused government policy to change. ${ }^{5}$

Another factor inhibiting the emergence of an organization representative of the interests of technical teachers was the large numbers of part-time teachers that made up the staffs of the technical institutes with their high proportion of evening classes. Even by 1913 there were only some 14,700 day students out of the $6,500,000$ persons aged between 15 and 24 in technical classes in England and Wales: this represented a mere $0.23 \%$ of the population in this age-group. However, the corresponding number of evening students in 1911 was 765,000 or $11.7 \%{ }^{6}$

Clearly, throughout the developmental period of English technical education, technical teachers not only were few in number absolutely and relatively to other teacher-groups, but also were characterized by a division within their own sector between full-time and part-time staff. For the smaller group of full-time teachers, teaching was their sole

${ }^{1}$ B. Webb, special supplements on "English Teachers and their Professional Organisation", in: New Statesman, 25 September 1915, pp. 2-16, and 2 October 1915, pp. 2-8.

2 ATTI, Proceedings for 1904-05, p. 1.

${ }^{3}$ They included specialist bodies like the National Society of Art Masters (1888) and the Training College Association (1892). Webb, loc. cit.

4 There was one local association, the West Riding Association of Teachers of Science, Art and Technology founded in Yorkshire about 1900. It was the first formal organization of technical teachers in England and later became the West Yorkshire branch of the ATTI. See The ATTI : The First Half-Century 1904-1954 (London, 1954), pp. 5 and 12.

5 See S. Cotgrove, Technical Education and Social Change (London, 1958), pp. 16ff., and M. Argles, South Kensington to Robbins: An Account of English Technical and Scientific Education since 1851 (London, 1964), pp. 1-29.

6otgrove, op. cit., p. 69. 
occupation and source of income. On the other hand as far as the larger group of "part-timers" were concerned, their employment as "instructors" in evening classes merely provided a secondary income which supplemented the wages they received from working as "craftsmen" in industry during the day-time. Their prime loyalties were to their jobs outside of technical edudation and they had little in common occupationally with their full-time counterparts.

A final problem facing technical teachers as an occupational group was the heterogeneous character of their work and the diverse nature of their qualifications - from "craft" to post-graduate degree level which gave them little identity of interest among themselves: they were technical "specialists" rather than technical "teachers". As a later memorandum sent by the Council of the ATTI to the Board of Education pointed out:

"Amongst subjects taught by members may be mentioned physical \& [sic] natural sciences, mechanical and electrical engineering, building trade subjects, cabinet making, carriage building, gun construction, silk weaving, sanitary engineering, agriculture, mining, typography, textile trades, gas manufacture, navigation, book-binding, silversmith's work, leather dyeing, etc. Each of these subjects requires peculiar qualifications, varying greatly in their nature."1

For these reasons, then, English technical teachers were still unorganized while other teachers' associations were becoming established between 1870 and 1900 .

It was only from 1889 that the fortunes of English technical education began to change. The roots of this may be traced back to the setting up of a Royal Commission on Technical Instruction in 1881 "to inquire into the Instruction of the Industrial Classes of certain Foreign Countries in technical and other subjects, for the purpose of comparison with that of the corresponding classes in this Country". ${ }^{2}$ The Commission was an index of the growing public interest in the part that might be played by technical education in the economic prosperity of the country in the face of growing foreign industrial competition.

The main recommendations of the Commission, which sat from 1881-84, were not in themselves far-reaching. The Commissioners

1 Council Minutes, 4 December 1909, ATTI Archives, Vol. VI: Minutes of Council Meetings, November 1908 - April 1913.

${ }^{2}$ Quoted Argles, op. cit., p. 31. 
considered that the main obstacle to the development of "technical instruction" was the inadequacy of the existing provisions for elementary and secondary education which consequently should be unified and expanded, especially in the scientific and technical areas. With regard to post-school education, their recommendations were confined to empowering school boards to organize science and art classes for young persons and artisans. ${ }^{1}$ But the most important impact of the Commission was the effect it had on influencing public opinion prior to the legislation of 1889 and 1890 .

The Technical Instruction Act of 1889 , with its amending Act of 1891, was a landmark in English technical education. It gave local authorities the power to support or aid the supply of technical or manual "instruction" by raising a penny rate which was to be administered by technical instruction committees. By 1900-01 £106,209 was being produced from the rates under the Act. ${ }^{2}$ This was followed in 1890 by the even more far-reaching Local Taxation (Customs and Excise) Act, by which certain sums out of customs and excise duties were allocated to local authorities either to relieve the rates or to subsidize technical education. ${ }^{3}$ Some credit for this was due to the agitation of the National Association for the Promotion of Technical Education, formed in 1887, whose aims were the passing of legislation on technical education. The main argument of the supporters of technical and scientific education was the contribution it might make to industrial prosperity in Britain. In this context the increasing severity of foreign industrial competition facing British manufacturers at this time gave weight to the advocates of technical education. ${ }^{4}$ Gradually, under pressure from the critics, the amount of "whiskey money" used for "technical instruction" increased "until by 1898, out of a total of $£ 807,000$ available, no less than $£ 740,000$ was being spent on education". 5

The result of this legislation, together with the educational effects of the 1870 Education Act, was a more rapid expansion of technical education during the 1890s than at any other time previously. By the turn of the century its salient features were established as a

1 For a summary of the main recommendation of the Royal Commission, ibid., pp. 32ff.

Ibid., p. 35.

3 Ibid.

4 Although British industrial output doubled between 1870 and 1913, world output increased fourfold. Further, whereas Britain produced about a third of the world's manufactured goods in 1870 , by the 1890 s it supplied only $20 \%$ of total world production. See W. Ashworth, An Economic History of England 1870-1939 (London, 1960), pp. 25-45.

5 Ibid. 
predominantly part-time form of education, which "concentrated mainly on training the technician, craftsman and office worker, and preparing students for external examinations". ${ }^{1}$ Between 1892 and 1899 , for example, there was a sixfold increase at evening classes conducted by school boards, but there were also some important innovations. For by 1902 part of the "whiskey money" had helped to provide twelve "Polytechnics"2 in London, thirteen technical institutes in the provinces and more than a hundred organized science schools. $^{3}$

The first London polytechnic, in Regent Street, had been opened by Quintin Hogg in 1881 and was an establishment to which he devoted, in his later years, his entire leisure and a very substantial sum of money. It had 5,000 students during its first year, 9,192 by 1892 , and nearly 12,000 by 1897.4 Hogg's example was followed by others in various parts of London, helped by money appropriated under the City Parochial Charities Act, while the Goldsmiths' Company undertook to found and maintain a polytechnic at New Cross. After 1892 further funds were available from the London County Council when it began to devote some of its "whiskey money" to these institutions. ${ }^{5}$

They offered a range of classes but gradually a demand for the provision of "external" university studies at the London polytechnics grew, despite the views of people like Hogg that they should concentrate on trade classes and elementary education and should not provide higher studies. Nevertheless by 1904 six polytechnics were providing complete degree courses and fifty of their teachers were recognized university teachers instructing 500 undergraduates. ${ }^{6}$ Clearly in such establishments a new and specialized category of teacher was beginning to emerge by the turn of the century. Such teachers, together with their full-time colleagues in the technical institutes, both in London

1 Cotgrove, op. cit., p. 67.

2 They were not like the German colleges of higher technology but "an English blend of philanthropy, adult education, and technical instruction". Argles, op. cit., p. 39.

${ }^{3}$ G. A. N. Lowndes, The Silent Social Revolution (London, 1937), p. 192. For details of the organized science schools, see Argles, op. cit., pp. 21 and 43.

"Cotgrove, op. cit., pp. 60-70. See also F. Johnson, "The London Polytechnics", London M.A. thesis, 1929.

\begin{tabular}{|c|c|c|}
\hline $\mathbf{s}$ & $\begin{array}{c}\text { "Whiskey Money" } \\
\text { given to } \\
\text { LCC }\end{array}$ & $\begin{array}{l}\text { Amount of "Whiskey } \\
\text { Money" spent on } \\
\text { technical education }\end{array}$ \\
\hline $1890-92$ & $£ 342,000$ & nil \\
\hline 1893 & $£ 200,000$ & $£ 29,000$ \\
\hline 1902-03 & $£ 200,000$ & $£ 180,000$ \\
\hline
\end{tabular}

Source: Argles, op. cit., p. 38.

- Cotgrove, op. cit., pp. $63 f$. 
and the provinces, had more in common among themselves than with the larger numbers of part-time evening staff to be found in every technical teaching centre. It needed only the impact of certain economic pressures, which were beyond their control, for them to provide the leadership for a new teachers' organization that could devote its energies to the particular problems of technical teachers.

\section{III}

After 1902 events moved fairly swiftly. A growing cause of dissatisfaction among the full-time teachers arose from the challenge to technical education, in the light of the recent progress made, from the educational reforms of the Education Act of 1902. It abolished the school boards and the technical instruction committees and coordinated all forms of public education under local authorities whose responsibilities now included the provision of secondary education. This was to be financed from government grants and the rates. ${ }^{1}$ This Act, while in the interests of the elementary and secondary sectors, had dire effects for technical education and did not lead to any immediate increase in its material facilities. As one writer has pointed out: "the number of first-class technical schools built between 1902 and 1918 can almost be counted on [...] two hands." 2 The reason for this was that the newly-formed Board of Education could not persuade the Exchequer to allow it the necessary resources to do more than one thing well, so it put as many funds as possible into elementary and secondary education. Consequently, as far as technical education was concerned, although the previous gains were not lost, little was done in the period 1902-1914 to lessen the gaps that still existed. ${ }^{3}$

Another factor that mobilized the technical teachers into collective action was a growing sense of grievance in matters relating to their pay and conditions of work in general. Salaries were negotiated on an individual basis in each institution so that there were no local, let alone national scales. Moreover, remuneration was often "far below that paid to a form master in a secondary school". 4 As a subsequent member of the Association, employed at the Chelsea Institute, wrote

1 Lowndes, op. cit., p. 192.

2 Ibid.

3 This theme constantly recurs in ATTI literature of the period. Refer, for example, to John Wilson's remarks in his presidential address at the annual conference, 18 June 1910: "The need of our activities as advocates of technical education is all the greater at a time like the present, when there is a danger of public attention being engrossed by the demands of elementary and secondary education." Journal of the ATTI, July 1910, p. 97.

4 Ibid., p. 105 
in 1905: "We are agitating for a scheme of salaries but our authorities do not think much of it."1 In addition, technical teachers worked longer hours than teachers elsewhere, owing to the nature of their work, which included evening classes, and very few had permanent appointments and security of tenure. Also there was no pension scheme for technical teachers, ${ }^{2}$ unlike the elementary teachers who were now contributing with the state to a fund established under the Teachers' Superannuation Act of $1898 .^{3}$

Finally, it was the example of the other teachers' organizations already in existence that emphasised their vulnerable position. For after 1902 technical teachers were the only section of employees in public education authorities without collective influence and without representation in educational affairs. The National Union of Teachers, for example, had secured representatives on the Consultative Committee of the Board of Education, ${ }^{4}$ one purpose of this body being to advise the Board on matters which the latter referred to it. ${ }^{5}$ Furthermore, the fact that the Association of Technical Institutions had been accorded representation on this Committee ${ }^{6}$ was an added grievance since it was an association of institutions, not of persons.?

It was these circumstances, then, that led to some preliminary meetings among groups of polytechnic and other technical teachers in London during May and June 1904. At a meeting on 29 June, at Birkbeck College, twenty-five representatives from eleven London institutions deemed it desirable to form "an Association of Science, Technological and Art Teachers engaged in the London Polytechnics, Art Schools and Technical Institutes [...] to comprise both permanent staff and evening teachers other than those engaged in purely secondary work". ${ }^{8}$ The decision that full membership should not be restricted to

1 Letter from W. W. Pullen, London, 9 May 1905, to V. A. Mundella, ATTI Archives, Vol. XXVIII: Minutes of Legal Committee, 1905-1912.

2 ATTI, Proceedings for 1906-07, pp. 52f.

3 J. W. Adamson, English Education 1789-1902 (Cambridge, 1930), p. 490.

4 Webb, loc. cit., 2 October 1915, p. 6.

5 See Education, 13 April 1906, p. 281, for further details.

- Webb, loc. cit., 2 October 1915, p. 6.

The ATI, formed in 1894 with an institutional membership of twenty-seven, had by 1914 grown to ninety-eight. Its objects were: "To promote the efficient organisation and management of technical institutions, facilitate concordant action among governing bodies, and aid the development of technical education throughout the U.K." See H. L. Haselgrave, "History of the ATI 1893-1919", in: Vocational Aspect, November 1950, p. 240.

${ }^{8}$ Meeting Minutes, 29 June 1904, ATTI Archives, Vol. IV : Minutes of Preliminary Meetings, 1904; First Annual General Meeting, 21 January 1905; Minutes of Council Meetings, February 1905 - October 1905. 
full-time teachers alone was only made after considerable discussion. ${ }^{1}$ The main factors were, it would seem, firstly that "Associate" membership for part-time teachers would have emphasised divisions between themselves and diminished potential unity and, secondly, that it would be financially preferable to accept them on a full-membership basis since they would have to pay the full subscription instead of a smaller one. ${ }^{2}$

Events culminated in a general inaugural meeting, attended by some 200 teachers from London technical institutions, on 22 October 1904, where it was decided to call the organization "The Association of Teachers in Technical Institutes". A Provisional Executive Committee was appointed "to draft rules and constitutions, and to report to a General Meeting to be held in January 1905". 3 By the end of November there were 150 members" $^{4}$ and "It was believed that the Association, though formed in the first place for London only, might later with advantage become national." 5

From the evidence available it is certain that without the devoted activity of a small group of London polytechnic teachers during this period it is doubtful whether the new association would have been formed. They provided the leadership and the administrative skills. Of the five signatories to the circular of September 1904, announcing the proposed general meeting at Birkbeck College, four were teachers in polytechnics. ${ }^{6}$ Also during the first three years of the Association's existence (1905-07), until its re-organization on a national basis after the first Annual Conference in May $1907,{ }^{7}$ its three presidents, ${ }^{8}$ and ten of the remaining twelve office-holders, were teachers in the London polytechnics. ${ }^{9}$

\section{IV}

From the outset the newly-formed Association sought to strengthen itself by recruiting from as wide an area as possible: only by so doing could it hope to become established and make its voice carry any

1 ATTI: The First Half-Century, p. 6.

2 Ibid.

3 ATTI, Proceedings for 1904-05, p. 1.

4 Letter from J. Wilson, London, 30 November 1904, to C. Harrap, ATTI Archives, Vol. V: Minutes of Annual General Meetings, 1905-1908; Minutes of Council Meetings, November 1905 - October 1908.

5 Recruiting leaflet, London, 1904, ATTI Archives, Vol. II.

- Pamphlet, London, September 1904, ATTI Archives, Vol. XLII: Folder containing copies of official documents, 1904-1916.

7 Circular to Members, London, 25 March 1907, ATTI Archives, Vol. II.

"One of these was designated as "Chairman".

- ATTI, Proceedings for 1904-05, 1905-07, et passim. 
weight in official circles. On 23 October 1904 John Wilson, the temporary Honorary Secretary, wrote to the West Riding Association of Teachers of Science, Art and Technology (WRATSAT) proposing that it combine with the London Association. They replied: "Any question or suggestion of affiliation that you have will, I am sure, receive the serious attention of our Council here." Shortly afterwards, at the general meeting of 21 January 1905, it was resolved "That the Council be instructed to consider, at an early date, the extension of the Association to the Provinces." at the same time letters were read from numerous provincial teachers wishing success to the Association and enquiring if membership were open to non-London teachers. ${ }^{3}$ In these circumstances the new Council took every opportunity to publicize the Association's activities and make known its aims and objectives:
A) The advancement of Technical Education generally.
B) The inter-change of ideas regarding the methods of Technical Teaching.

C) The promotion and safeguarding of professional interests in such matters as Tenure, Salaries, Pensions, Registration, Training and Qualifications of Teachers, Schemes of Examination and Inspection.

D) To lay the views of Technical Teachers before the various Educational Authorities and the Public.

E) To enable Teachers in Technical Institutes to co-operate as a body with other Educational or Scientific Associations when desirable. F) To render legal advice and assistance to members wherever possible and desirable.

G) To institute an Employment Bureau.

H) To create a Benevolent Fund for needy members, as soon as the society shall be strong enough to do so. ${ }^{4}$

It was on the basis of these objectives, and their subsequent attempts to implement them, that the Association's membership expanded steadily in the period up till 1914. Table 1 summarizes this growth. It shows that, for this period, the development of the ATTI can be divided into three phases 1) 1904-1907, 2) 1908-1910 and 3) 1911-1913.

The first phase corresponded with the rapid growth of the Association from the end of 1904 till the end of 1907, by which time its

${ }^{1}$ Letter from WRATSAT, Leeds, 26 October 1904, to ATTI, ATTI Archives, Vol. IV.

2 ATTI, Proceedings for 1904-05, p. 4.

3 General Meeting Minutes, 21 January 1905, ATTI Archives, Vol. IV.

4 Recruitment leaflet, London, (May?) 1905, ATTI Archives, Vol. XLII. The above are also to be found virtually unmodified in the various Constitution and Rules of the Association $1905 \mathrm{ff}$. 
Table 1: ATTI Membership Growth, 1904-1914

$\begin{array}{lcccc}\begin{array}{l}\text { End of } \\ \text { Year }\end{array} & \begin{array}{c}\text { Number of } \\ \text { Members }\end{array} & \begin{array}{c}\% \text { increase } \\ \text { on previous } \\ \text { year }\end{array} & \begin{array}{c}\text { New } \\ \text { branches } \\ \text { formed }\end{array} & \begin{array}{c}\text { Total number } \\ \text { branches* }\end{array} \\ 1904 & 150 & - & - & - \\ 1905 & 300 & 100 & - & - \\ 1906 & 474 & 58 & 4 & 4 \\ 1907 & 696 & 47 & - & 7 \\ 1908 & 708 & 2 & 2 & 9 \\ 1909 & 740 & 5 & -3 * * & 12 \\ 1910 & 792 & 7 & 1 & 13 \\ 1911 & 939 & 19 & - & 15 \\ 1912 & 1,076 & 15 & & \\ 1913 & 1,158 & 8 & & \\ 1914 & 1,200 * * * & 3 ? & \end{array}$

Sources: ATTI, Proceedings for 1904-05; 1905-06; 1906-07; Journal of the ATTI for 1908, 1909 and 1910; The Technical Journal for 1911, 1912, 1913 and 1914; et passim.

numbers had increased over four-and-a-half-fold and seven branches had been established. During 1905 membership consisted largely of London teachers, but the following year saw further recruitment and the formation of branches in the provinces. This new situation was reflected in the change of name to that of "The Association of Teachers in Technical Institutions" at the (second) Annual General Meeting on 27 October 1906. ${ }^{1}$ This time was a critical one for unless the Association had established itself on a firm numerical and financial basis then its existence would have been endangered. That it managed to survive during these years was due partly to its satisfying the need among English technical teachers for such an organization, partly to the effective recruiting methods of the Council and branch members, and partly to the sound administration of its honorary officers.

It took, however, another three years, from 1908 till 1910, to obtain a further hundred members and two more branches. It would seem that the economic uncertainties of 1908 and 1909, as reflected in the high levels of unemployment, ${ }^{2}$ would have had repercussions on technical education and a regressive effect on recruitment. The latter

1 Report of the Annual General Meeting, 27 October 1906, ATTI Archives, Vol. II.

2 See W. Johnson, J. Whyman, G. Wykes, A Short Economic and Social History of Twentieth Century Britain (London, 1967), p. 134. 
was also affected by the raising of subscriptions from $5 /-$ per year to a minimum of $7 / 6$ during $1907 .{ }^{1}$

If the first phase in the Association's development was one of swift expansion, and the second was one of levelling out, then the third phase, from the beginning of 1911 till the end of 1914, was one of consolidation and added growth. By this date, as Table 1 shows, the Association had some 1,200 members in fifteen branches spread over England, Wales, Scotland and Ireland and could claim to be truly "National" in composition. Its history over the first ten years of its existence sustains the view of the president at the Annual Conference in 1914: "When the limited field upon which we have to draw is borne in mind, it must be admitted that the growth has been highly satisfactory."2

The analysis of total membership trends between 1904 and 1914 is, however, only one aspect of the ATTI's growth. The questions arise what part did the branches ${ }^{3}$ have in this development, and how was membership distributed among them? With regard to the first point, although the first branch was formed in Cornwall, which held its inaugural meeting on 10 February $1906,{ }^{4}$ the most significant events in the early period were those leading up to the amalgamation of the WRATSAT with the London-based Association in June 1906.

Correspondence between London and Yorkshire had been exchanged as early as October $1904^{5}$ and in December the WRATSAT had stated its desire "to approach the London Association [...] and expresses a hope that the question of forming a National Association will be favourably considered". 6 Negotiations continued throughout 1905 but it was not until the end of the year that it was agreed that the Yorkshire Association should become the "West Yorkshire Section" for a year "not as a branch but as a co-ordinate Association [...] with a view to a complete affiliation by the formation of a National Association at the end of

1 Journal of the ATTI, October 1908, p. 5.

2 The Technical Journal, July 1914, pp. $100 f$.

3 The Association's "branches" were not located at "institute" level but were based on wide geographical areas covering a number of establishments. For example, in 1908 the London branch contained 301 members from more than 60 institutes spread over London and the Home Counties. See Journal of the ATTI, October 1908, pp. 51-61.

ATTI, Proceedings, for 1905-06, p. 67.

Supra, pp. $385 f$.

- Resolution passed by the WRATSAT, 19 December 1904, ATTI Archives, Vol. IV. 
that time". 1 These somewhat protracted discussions derived from provincial susceptibilities and suspicion that the London Council might dominate any subsequent union. In the event the final meeting of the WRATSAT was held on 7 April 1906 when it was united with the City of Bradford Technical College Staff Association to form the "West Yorkshire Section" of the Association of Teachers in Technical Institutes."

A conference of delegates from Yorkshire and London was held in June when it was decided to rename the "West Yorkshire Section" the West Yorkshire branch, and that a London branch should be formed. ${ }^{\mathbf{3}}$ The inauguration of other branches in West Lancashire in May, and East Lancashire in September brought their total number to five by the beginning of 1907,4 to which a Birmingham branch and an East Midland branch were added by September. ${ }^{5}$ The subsequent growth

\section{Table 2: ATTI Branches, 1908-1913}

Membership numbers per branch (End of) $1908 \quad 1909 \quad 1910 \quad 1911 \quad 1912 \quad 1913$

\begin{tabular}{lrrrrrrr} 
Cornwall* & \multicolumn{1}{c}{ (formed 1906) } & 21 & 18 & 21 & 22 & 19 & 21 \\
West Yorkshire** & $(1906)$ & 131 & 123 & 140 & 164 & 180 & 184 \\
West Lancashire & $(1906)$ & 115 & 112 & 111 & 111 & 114 & 119 \\
East Lancashire & $(1906)$ & 52 & 53 & 60 & 74 & 116 & 115 \\
London & $(1907)$ & 301 & 279 & 250 & 261 & 271 & 280 \\
Birmingham*** & $(1907)$ & 48 & 58 & 75 & 82 & 78 & 81 \\
East Midlands & $(1907)$ & 18 & 15 & 26 & 31 & 38 & 29 \\
Glasgow and West Scotland & - & 29 & 49 & 46 & 42 & 38 \\
Northumberland and Durham**** & - & 36 & 41 & 41 & 39 & 46 \\
Northern Ireland (inc. Dublin) & - & - & - & 32 & 61 & 72 \\
South Wales & & - & - & - & 37 & 39 & 48 \\
Dundee & - & - & - & 8 & 12 & 12 \\
Hull (sub-branch) & & - & - & - & 16 & 19 & 18 \\
Southern Counties & - & - & - & - & 33 & 34 \\
Leicester & - & - & - & - & - & 17 \\
Southern Ireland & - & - & - & - & - & 27 \\
Others & 22 & 17 & 19 & 14 & 15 & 17 \\
Total & 708 & 740 & 792 & 939 & 1076 & 1158
\end{tabular}

* Became South-Western branch 1913.

** A South Yorkshire branch was formed in 1910 but re-amalgamated shortly afterwards with West Yorkshire.

*** Became South-Midland branch 1909.

**** Became North-Eastern branch 1913.

Sources: see Table 1.

1 Letter from the WRATSAT, Leeds, 23 December 1905, to the ATTI, ATTI Archives, Vol. V.

2 Education, 20 April 1906, p. 284.

3 ATTI: The First Half-Century, p. 12.

4 ATTI, Proceedings for 1905-06, p. 6.

5 ATTI, Proceedings for 1906-07, p. 29. 
of these branches and the formation of others are shown in Table 2.

From this it is apparent that although by the end of 1913 there were fifteen branches within the Association, membership distribution was heavily concentrated in five of the seven branches formed between 1906 and 1907. Thus, at the end of 1908, the Yorkshire, West Lancashire, East Lancashire, London, and Birmingham branches accounted for $92 \%$ of total branch membership: by 1913, with eight more branches, and a $64 \%$ increase in total membership, these five branches still contained $67 \%$ of all members. In addition, the ranking order of these branches, by absolute size, was the same at both dates, namely London, Yorkshire, West Lancashire, East Lancashire and Birmingham. Nonetheless, while membership had gone up absolutely in West Lancashire by only 3.5\% and had actually fallen in London by $7 \%$, in East Lancashire, Birmingham and West Yorkshire it had increased by $121 \%, 69 \%$, and $41 \%$ respectively between these years. These changes in absolute branch size reflected two main developments in relative terms, as indicated in Table 3 , the comparative decline of the London, West Yorkshire and East Lancashire branches and the comparative growth in the East Lancashire and Birmingham areas. Therefore numerically the Association continued to rely heavily on those branches, in 1913, that had been instrumental in its "nationalisation" in the formative period up till 1908, despite its total growth in the intervening years. Indeed, of the eight branches formed after 1908, only three - Northern Ireland, South Wales and the North-East had over forty members each five years later. However, within the "big five" the relative pattern of membership distribution had changed.

These overall and distributive changes among the five largest branches of the Association derived from their internal evolution between 1908 and 1913. Although at both of these dates each of these branches was characterized by a membership which was drawn from a range of geographically dispersed institutes, they were distinguished

\section{Table 3: The five largest ATTI Branches as a Proportion of Total Membership, 1908 and 1913}

$$
\begin{gathered}
\text { Branch as \%age of } \\
\text { total membership }
\end{gathered}
$$

1908

London

West Yorkshire

West Lancashire

East Lancashire

Birmingham
42.5

18.5

16.3

7.4

6.8
Branch as \%age of total membership

1913

24.2

15.9

10.3

10.0

7.0

Source: see Table 2. 
Table 4: Percentage ATTI Membership Distribution per Institute by Branch, 1908 and 1913

\begin{tabular}{|c|c|c|c|c|c|c|c|c|c|c|}
\hline \multirow{2}{*}{$\begin{array}{l}\text { Members } \\
\text { per } \\
\text { Institute }\end{array}$} & \multicolumn{2}{|c|}{ London } & \multicolumn{2}{|c|}{$\begin{array}{c}\text { West } \\
\text { Yorkshire }\end{array}$} & \multicolumn{2}{|c|}{$\begin{array}{c}\text { West } \\
\text { Lancashire }\end{array}$} & \multicolumn{2}{|c|}{$\begin{array}{c}\text { East } \\
\text { Lancashire }\end{array}$} & \multicolumn{2}{|c|}{ Birmingham } \\
\hline & 1908 & 1913 & 1908 & 1913 & 1908 & 1913 & 1908 & 1913 & 1908 & 1913 \\
\hline $1-4$ & 79.2 & 75.8 & 86.3 & 72.5 & 87.5 & 80.6 & 87.4 & 75.0 & 88.2 & 88.0 \\
\hline 5- 9 & 4.8 & 8.6 & 9.1 & 15.0 & 10.0 & 9.7 & 8.3 & 4.2 & 5.9 & 8.0 \\
\hline $10-14$ & 6.4 & 6.9 & 2.3 & 2.5 & 0.0 & 6.5 & 4.3 & 12.4 & 0.0 & 0.0 \\
\hline $15-19$ & 4.8 & 3.5 & 0.0 & 5.0 & 0.0 & 0.0 & 0.0 & 4.2 & 5.9 & 0.0 \\
\hline $\begin{array}{l}20 \text { and } \\
\text { over }\end{array}$ & & & & & & & & & & \\
\hline over & 4.8 & 5.2 & 2.3 & 5.0 & 2.5 & 3.2 & 0.0 & 4.2 & 0.0 & 4.0 \\
\hline
\end{tabular}

Sources: Journal of the ATTI, October 1908, pp. 42-67; The Technical Journal, November 1913, pp. 268-304.

in 1913 from the other ten branches by two features. Firstly, their regional constituencies contained a larger number of institutes from which to draw members, hence their potential recruitment areas were greater. Secondly, in addition to their higher absolute membership figures, the proportion of these branches with members concentrated in larger institutes had grown over this five-year period as Table 4 illustrates.

By 1913 in each of these branches the percentage of members located in institutes with less than five members had diminished, and the proportion of those with more than twenty members per institute had increased. Thus while the "big five" were consolidating membership in the larger technical establishments in their areas, in the smaller more numerous institutes in those districts membership was increasing, in most cases, in the middle-ranges between five and fourteen members per institute. Also, whereas in 1908 there had only been five institutes with more than twenty members each, ${ }^{1}$ in 1913 the number had increased to ten. ${ }^{2}$ However, the latter only included two organizations, Portsmouth Technical College and Derby Technical College, which were not part of these five largest branches. ${ }^{3}$

1 Journal of the ATTI, October 1908, pp. 42-67, et passim. Of this group three institutes were located in London, one in West Yorkshire, and the other in West Lancashire. Ibid.

2 Journal of the ATTI, November 1913, pp. 268-304, et passim. These included three institutes from London, two from West Yorkshire, and one each from West Lancashire, East Lancashire and Birmingham. Ibid. Among these, Liverpool Technical School, Bradford Technical College, Regent Street Polytechnic (London), and Battersea Polytechnic (London) had had over twenty members each in 1908.

3 Ibid. They belonged to, and were predominant in, the Southern Counties branch and East Midland branch respectively. 
So far, the reasons for the late emergence of the ATTI, its formation, and its pattern of growth and membership distribution have been analysed. Three tasks remain: an assessment of its achievements, a consideration of its limitations, and an interpretation of its functions.

The Association's greatest success was that it managed to survive. The facts that an organization for technical teachers not only had been created where none had existed before, but also had expanded steadily so that by 1911 some $50 \%$ of the full-time staff of technical institutes throughout the U.K. had been recruited, ${ }^{1}$ were notable attainments. ${ }^{2}$ The first phase in the ATTI's history ends in 1914. The next four years were a watershed in its development, as teachers were called up and not replaced and classes abandoned. Yet without the strong foundations that had been laid down between 1904 and 1914, the Association would not have recovered from the vicissitudes of the war period and been able to resume, after the cessation of hostilities, where it had left off in 1914.

The credit for this success must be attributed to the small group of London polytechnic teachers who had originally conceived of the Association, and who continued, with other of their London associates, to provide a vigorous and effective leadership in these early, crucial years. Even after its expansion into the provinces, these teachers retained the key posts as honorary officers, and were therefore able to dominate, albeit benevolently, the executive committee which

1 The Technical Journal, July 1911, p. 157. Yet it was felt "That it is desirable [...] to induce a larger number of part-time teachers to become members." Council Minutes, 4 February 1911, ATTI Archives, Vol. VI. Part-time teacher membership was clearly important for the Association because of the large proportion of staff they constituted in technical institutes throughout the country and because of the potential financial advantages that their inclusion offered to the Association. Unfortunately it is impossible to ascertain from existing records their membership strength during the period 1904-1914, since it was only from 1922 that the ATTI separated out part-time from full-time membership. However, two particular problems hampered the recruitment of part-time staff to the Association. Firstly, the majority of part-time teachers worked in small, geographically scattered institutes. Secondly, since they were engaged in full-time employment elsewhere, it was likely that many of them were members of other unions or associations.

2 This was especially so in view of the fact that when the Burnham Technical Committee was set up in December 1920, although the majority representation was accorded to the ATTI, the National Union of Teachers, the National Society of Art Masters, the National Federation of Class Teachers, and the Association of Principals in Technical Institutions were also included on the panel. ATTI: The First Half-Century, p. 21. Hence it is very probable that between 1904 and 1914 the Association was in competition with such teachers' organizations for certain groups of "specialist" and "general" teachers. 
conducted "The business of the Association [...] between the time of Council Meetings". ${ }^{1}$ Indeed, for the seven years between 1907-08 and 1913-14, six polytechnic teachers and two associates from other London institutes provided five presidents, all seven secretaries, all seven treasurers, and eight out of twenty-one vice-presidents. ${ }^{2}$ Their collective influence was clearly paramount throughout this period.

In attaining the objectives ${ }^{3}$ for which it had been formed, however, especially those relating to the employment and occupational interests of its members, the ATTI's achievements were extremely limited. With respect to pay and conditions one London member, whose experience was typical of other teachers' situations, had written in 1905 to the Chairman of the Legal Committee: "I was appointed [...] without any written agreement. [...] The question of salary for all the staff is considered yearly. Each individual being considered separately $\&$ [sic] increases granted according to the circumstances. There is no fixed scale of salary." Another complained that in his institute there were "raw fellows taken straight from the works commencing to teach some subject at the same rate of pay as another with 20 years experience behind him". 5 Yet by 1914 no national salary scales which the Association wanted ${ }^{6}$ had been established, while Council's attention was still being drawn to advertisements for posts where "The successful candidate is requested to teach 30 hours a week exclusive of preparation and correction work, and there are 46 academic weeks per year".?

What can account for the Association's failure in these areas? Firstly, it was neither large enough ${ }^{8}$ nor strong enough to put direct pressure upon the Board of Education and the local authorities. Its position was one of weakness in view of the non-accommodating attitudes of the public bodies. Secondly, there was no institutional machinery either for consultation or negotiation on employment matters. All the Association's deliberations were on a ad hoc basis and

1 Council Standing Orders, 1908-09, ATTI Archives, Vol. VI.

2 The sources of this information are the same as those of Table 1.

3 Supra, p. 386.

4 Letter from Helen Maxlow, London, 3 May 1905, to Chairman of Legal Committee, ATTI Archives, Vol. XXVIII.

${ }^{5}$ Letter from E. A. Atkins, Liverpool, 1 October 1907, to Chairman of Legal Committee, ATTI Archives, Vol. XXVIII.

'See "Proposed Scale of Salaries", in Executive Committee Minutes, 19 February 1909, ATTI Archives, Vol. XVII.

7 Council Minutes, 10 January 1914, ATTI Archives, Vol. VII: Minutes of Council Meetings, May 1913 - April 1922. The Association wanted a 30 hour week for 36 weeks of the year.

${ }^{8}$ Compared, say, with the NUT's 91,500 members. Webb, loc. cit., 25 September 1915, p. 3. 
its methods of deputation, exhortation and publicity were bound to fail without the power to back them up. Thirdly, the ATTI, through the Teachers' Registration Council, was unable to control entry into technical teaching, because the Register was an ineffective instrument in that it failed to standardize the qualifications required for teaching employment. ${ }^{1}$

In conclusion, therefore, was the ATTI, by acting in the ways it did, a professional association, as it purported to be or a trade union? The statement, for example, by the President, V. A. Mundella, at the first Annual Conference in 1907 that "Since the inception of this Association we have all, I think, agreed that it should become in no sense a Trades Union of Teachers, but that our labour of love should be for the benefit of technical education. [...] Teaching is one of the greatest professions" 2 , must be counter-balanced by the earlier assertion that "It is not likely that your Council, acting on behalf of all of you, will remain inactive when it finds any real injustice being perpetrated."3

In the sense that the ATTI sought to raise standards jof entry into teaching through the Registration Council, was concerned with improving the quality of teaching, and desired "The advancement of Technical Education generally", 4 its activities were those of a professional body. Nevertheless, in its collective attempts to push up salaries, to assert a right to a pension, ${ }^{5}$ to limit the number of hours worked, and to protect the individual teacher from the caprices of his employers, the ATTI, was pursuing a market function "for the purpose of protecting and advancing [...] its members' economic interests in connection

${ }^{1}$ See G. Baron, "The Teachers' Registration Movement", in: The British Journal of Educational Studies, May 1954, pp. 113-144. The Council was established by Order in Council on 29 February 1912. It was composed of representatives of the elementary schools, secondary schools, technical institutes and the universities, together with Crown nominees and co-opted members. It laid down that an applicant must have proof of an academic qualification, of training in teaching, and of not less than three years teaching experience. Yet since a saving clause provided that up till 1918 anyone over twenty-five who had taught for five years could enrol, it was no more effective than the first register either in conferring status upon those who enrolled or in controlling entry into teaching. Furthermore, the Board of Education gave no official standing to the Council's rulings. Ibid.

2 ATTI, Proceedings for 1906-07, p. 50.

${ }^{3}$ Report of the Annual General Meeting, 27 October 1906, ATTI Archives, Vol. II.

4 Supra, p. 386.

${ }^{5}$ Although a superannuation scheme was promised by the government in 1912, the outbreak of war delayed matters till a Superannuation Act was passed in 1918. Yet it was not collective action by the technical teachers alone that had brought success, for they had acted in concert with other teachers' associations, including the National Union of Teachers. ATTI: The First Half-Century, p. 10. 
with their daily work". ${ }^{1}$ In short, in these objectives, and in its methods to achieve them the Association was showing a marked approximation to a trade union organization. Moreover, the trade union function was bound to become the main one. For unlike most professional men at this time, the technical teachers not only were unable to govern entry into their occupation but also did not make their "income" bargains individually with private members of the community, but each had to arrange his own terms of employment with a parsimonious public bureaucracy. In the longer term the only way of protecting their economic interests vis a vis their employers was for technical teachers to replace deputation through the ATTI, as between 1904 and 1914, by collective bargaining between employer and union. By 1914, then, insofar as it was concerned with its members' terms and conditions of employment, the ATTI was, by pressure of circumstances, already emerging as an embryonic white-collar trade union.

1 G. D. H. Cole, An Introduction to Trade Unionism (London, 1953), p. 13. 